Endocrinol. Japon. 1987, 34 (4), 621-626

\title{
NOTE
}

\section{A Case Report of Growth Attenuation during Methionyl Human Growth Hormone Treatment}

\author{
Yoshiaki OKADA ${ }^{1}$, Koji TAIRA ${ }^{2}$, Kazue TAKANO $^{3}$ and Naomi HIZUKA ${ }^{3}$ \\ 1 Okada Clinic, Osaka 541, Japan \\ 2 Department of Pediatrics, National Senboku Hospital, Sakai 590, Japan \\ 3 Department of Medicine, Institute of Clinical Endocrinology, Tokyo \\ Women's Medical College, Tokyo 162, Japan
}

\begin{abstract}
A 10-year-old child with idiopathic growth hormone deficiency was treated with recombinant methionyl human growth hormone (m-hGH, Somatonorm $\left.{ }^{\circledR}\right)$ at a dose of $14 \mathrm{IU} /$ week. Height increased from 122.3 to $126.5 \mathrm{~cm}$ during the first 9 months of treatment $(5.6 \mathrm{~cm} / \mathrm{y})$, but only from 126.5 to $126.6 \mathrm{~cm}$ during the next 3 month of treatment $(0.4 \mathrm{~cm} / \mathrm{y})$. Anti-hGH antibody was detected at 2 months of treatment, reached its maximum at the end of 9 months with a titer of $10^{6}$ and a binding capacity of $2.0 \mathrm{mg} / \mathrm{L}$. After switching from $\mathrm{m}-\mathrm{hGH}$ to pituitary extracted hGH (p-hGH) treatment, his height increased again from 126.6 to $132.2 \mathrm{~cm}$ during the next 12 months of p-hGH treatment $(5.6 \mathrm{~cm} / \mathrm{y})$. The cause of growth attenuation during $\mathrm{m}-\mathrm{hGH}$ treatment was concluded to be the high titer of anti-hGH antibody. This is the first case in Japan and one of only three cases in which growth attenuation occurred during $\mathrm{m}$-hGH treatment.
\end{abstract}

Treatment of growth-hormone-deficient children with recombinant methionyl human growth hormone $(\mathrm{m}-\mathrm{hGH})$ has been studied since 1982. By several investigators it has been confirmed that the growth promoting effect of $\mathrm{m}-\mathrm{hGH}$ is comparable to that of pituitary-extracted $\mathrm{hGH}(\mathrm{p}-\mathrm{hGH})$ (Takano et al., 1983, Bierich 1986, Takano and Shizume 1986, Takano et al.. 1986, Milner

\section{Received January 14, 1987}

Address all correspondence and requests for reprints to: Dr. Yoshiaki Okada, Okada Clinic, Katano Bld. 3F, 3-39, Kitahama, Higashi-ku, Osaka 541, Japan et al., 1986, Girard and Gourmelen 1986, Vincens-Colvet 1986, Westphal 1986, Kaplan et al., 1986, Bierich et al., 1986). The only apparent difference between the result of $\mathrm{m}-\mathrm{hGH}$ treatment and that of $\mathrm{p}-\mathrm{hGH}$ treatment was the great antigenicity of $\mathrm{m}-\mathrm{hGH}$. The incidence of antibody appearance ranged between 22 to $88 \%$ as reported by the investigators mentioned above. Anti-hGH antibody produced by $\mathrm{m}-\mathrm{hGH}$ administration did not show any effect on growth increase during treatment in most of the patients.

In this paper we report a patient with GH deficiency who showed growth attenua- 
tion during $\mathrm{m}-\mathrm{hGH}$ treatment, probably because of the high titer of anti-hGH antibody.

\section{Case Report}

A ten-year-old boy was referred to our clinic to determine the reason for his short stature. He was born at 38 weeks and 3 days of gestation in vertex presentation and weighed $3300 \mathrm{~g}$ at birth. He had been in good health during childhood and his height was between -2 and $-3 \mathrm{SD}$ of the mean height for Japanese boys of the same age group. His height increased $3.5 \mathrm{~cm}$ during the year before we examined him. When he visited our clinic, physical examination revealed a short child with a height of $120.6 \mathrm{~cm} \mathrm{(-2.6} \mathrm{SD)} \mathrm{and} \mathrm{body} \mathrm{weight} \mathrm{of}$ $26.2 \mathrm{~kg}(-1.0 \mathrm{SD})$. Bone age was 7.0 years. The laboratory data are shown in Table 1. Plasma GH did not increase to above $5 \mathrm{ng} /$ $\mathrm{ml}$ in either insulin induced hypoglycemia or in an arginine infusion test. His thyroid and adrenal functions were within the normal range. Urine volume and gravidity were normal. His lateral skull X-rays and CT scan were normal. According to the criteria of hGH deficiency, he was diagnosed as idiopathic growth hormone deficient.

Methionyl hGH treatment was started after obtaining the informed consent of his parents. The patient was seen every month and at each visit physical and laboratory examinations were carried out. The clinical and laboratory findings during the treatment are shown in Table 2 and Fig. 1. His height increased $3.2 \mathrm{~cm}$ during the first 6 months of treatment. However,

Table 1. Laboratory data

Time after stimulation, min.

GH stimulation test

$\begin{array}{lllll}0 & 30 & 60 & 90 & 120\end{array}$

Insulin induced hypoglysemic test (ITT)

$\begin{array}{lllllll}\text { GH } & (\mathrm{ng} / \mathrm{ml}) & 1.8 & 1.6 & 2.0 & 2.1 & 2.1 \\ \text { BS } & (\mathrm{mg} / \mathrm{dl}) & 78 & 32 & 44 & 52 & 60\end{array}$

Arginine infusion test $\mathrm{GH}(\mathrm{ng} / \mathrm{ml})$

$\begin{array}{lllll}0.8 & 2.8 & 1.1 & 1.0 & 0.7\end{array}$

Other hormone (basal level)

$\mathrm{T}_{3} ; 1.31 \mathrm{ng} / \mathrm{ml}, \mathrm{T}_{4} ; 9.7 \mu \mathrm{g} / \mathrm{dl}, \mathrm{TSH} ; 3.0 \mu \mathrm{U} / \mathrm{ml}$ cortisol; $8.9 \mu \mathrm{g} / \mathrm{dl}$, SM-C ; not determined

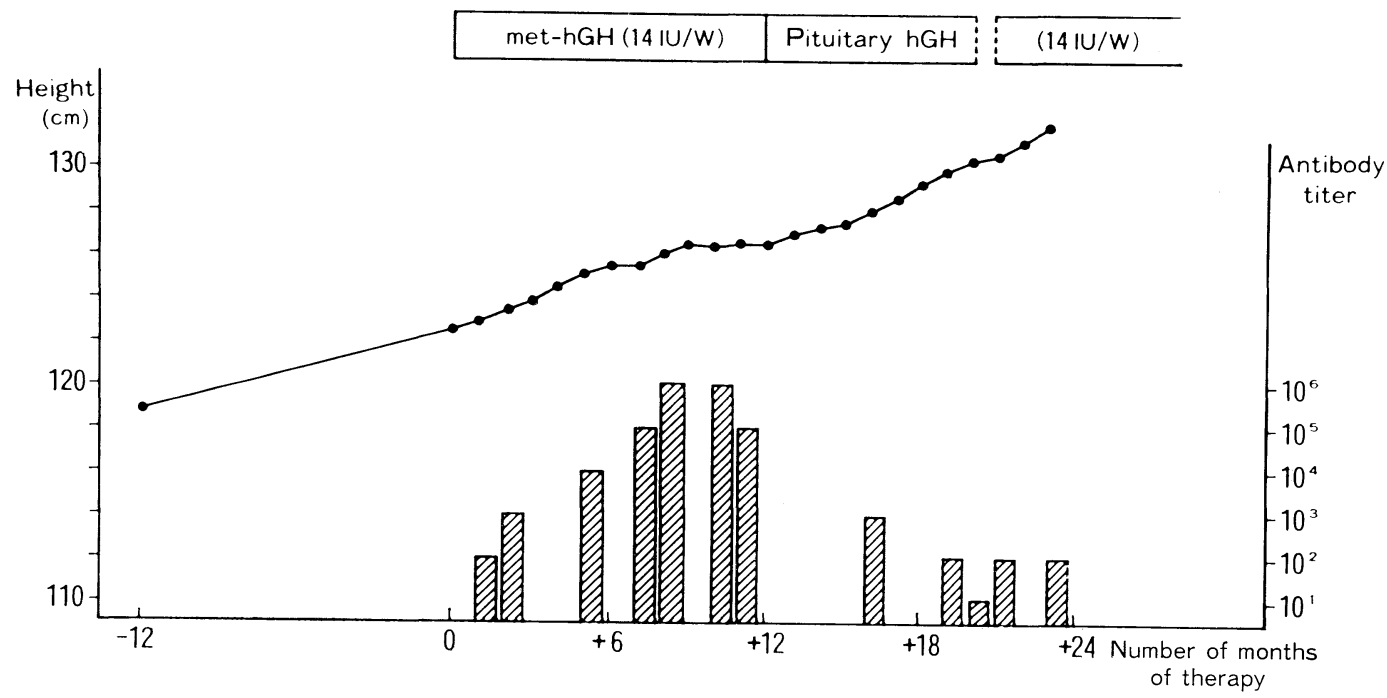

Fig. 1. Growth curve and titer of anti-hGH antibody in a GH deficient child treated initially with m-hGH (Somatonorm III) for one year and later with p-hGH. Growth attenuation occurred at 9-12 months of treatment. 


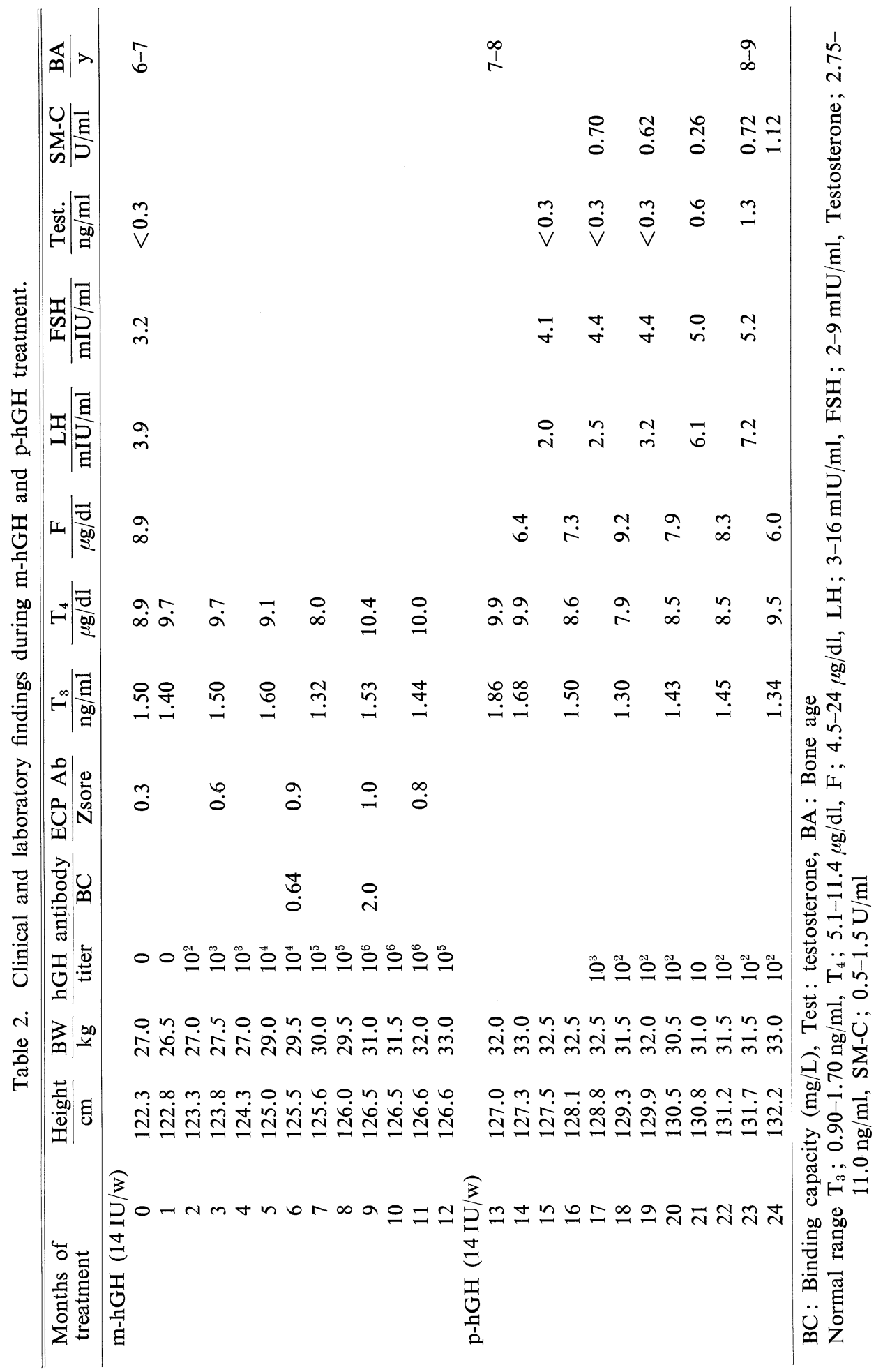


it increased only $1.0 \mathrm{~cm}$ during the second 6 months of $\mathrm{m}-\mathrm{hGH}$ treatment. Notably his height failed to increase during treatment in the 9 th to 12 th months. Anti-hGH antibody was detected after 2 months of treatment with a titer of $10^{2}$, after which the titer increased gradually and was $10^{6}$ at the end of 9 months of treatment. The binding capacity of anti-hGH antibody was 0.64 and $2.0 \mathrm{mg} / \mathrm{L}$ at 6 and 9 months of treatment, respectively.

After one year of treatment with $\mathrm{m}-\mathrm{hGH}$, the treatment was switched to pituitary extracted hGH (p-hGH: Nanormone $\left.{ }^{\circledR}\right)$. His height then started to increase, and during the first 6 months of p-hGH treatment it increased $2.7 \mathrm{~cm}$, and it increased $2.9 \mathrm{~cm}$ during the second 6 months of p-hGH treatment. These two values were greater than that observed during 6 months of $\mathrm{m}-\mathrm{hGH}$ treatment in months 6 to 12 . The titer of anti-hGH antibody gradually declined and was $10^{2}$ at the end of 24 months of treatment.

Plasma $T_{3}, T_{4}$ and cortisol did not change significantly during $\mathrm{GH}$ treatment. Plasma SM-C remained normal during treatment except for one reading of $0.26 \mathrm{U} / \mathrm{ml}$, when the patient did not receive an injection of p-hGH for 3 weeks. Puberty started at 20 months of therapy, since plasma FSH, LH and testosterone began to rise. The bone age changed with the chronological age.

\section{Materials and Methods}

Commercial radioimmunoassay kits were used to determine the following hormones: $\mathrm{GH}, \mathrm{T}_{3}$, $\mathrm{T}_{4}$, cortisol, $\mathrm{LH}, \mathrm{FSH}$, testosterone and somatomedin C (Eiken immunochemical Co., Ltd., Tokyo). Anti-hGH antibody was measured by a polyethylene glycol procedure using multiple dilutions of the patient's serum. The serum sample was considered positive if the binding percentage was more than twice that of control serum binding. A serum sample was diluted in a ten fold series and the titer of the antibody was expressed as weakest solution of the serum at which the binding was less twice the control binding. The binding capacity of anti-hGH antibody was measured by Scatchard plot analysis (Scatchard 1949) at KabiVitrum AB (Stockholm, Sweden). Antibodies to Escherichia coli protein (ECP) were quantitated by an immunoradiometric assay by KabiVitrum AB (Stockholm, Sweden). Bone age was estimated according to the standards of Greulich and Pyle (1959).

The recombinant methionyl hGH (m-hGH) used in this patient was a highly purified preparation, Somatonorm III (No. 89825), kindly supplied by Sumitomo Pharmaceutical Co. Ltd. (Osaka, Japan) and KabiVitrum AB (Stockholm, Sweden). One vial contained $4 \mathrm{IU}$ of hGH, 40 $\mathrm{mg}$ of glycine, $1 \mathrm{mg}$ of sodium phosphate and 3-4 ng of ECP. The patient received sc injections of $14 \mathrm{IU} /$ week on three or four occasions.

\section{Discussion}

Here we have reported a patient with GH deficiency, who showed growth attenuation during $\mathrm{m}-\mathrm{hGH}$ treatment. We concluded that the cause of growth attenuation was the high titer of anti-hGH antibody, because there were no other factors likely to affect height increase in this patients; for example, hypothyroidism, malnutrition, advanced bone age or combined therapy with other drugs.

Two other cases who showed growth attenuation during $\mathrm{m}-\mathrm{hGH}$ treatment have been described in literature. One case was reported by Kaplan et al. (1986). The patient was 14 years-old and had received radiotherapy and chemotherapy for nasopharyngeal carcinoma before $\mathrm{m}$-hGH treatment. He was treated with a highly purified $\mathrm{m}-\mathrm{hGH}$ preparation $(\mathrm{G}-15$ Genentech, $\mathrm{ECP}<$ $30 \mathrm{ng} / \mathrm{vial}$ ) for one year. After one year of therapy, he had high-titer antibodies of $10^{4.6}$ with binding capacities of $18-29 \mathrm{mg} / \mathrm{L}$ and his growth rate declined to less than $2 \mathrm{~cm} / \mathrm{y}$. After changing from $\mathrm{m}-\mathrm{hGH}$ to $\mathrm{p}-\mathrm{hGH}$, his growth rate increased to $8.6 \mathrm{~cm} / \mathrm{y}$ over a period of 8 months and his antibody binding capacity fell to $4 \mathrm{mg} / \mathrm{L}$. The other case was reported by Bierich et al. (1986). 
He was a non-idiopathic growth-hormone-deficient child and received the first preparation of $\mathrm{m}-\mathrm{hGH}$ (Somatonorm I from KabiVitrum), which contained $600 \mathrm{ng}$ ECP per vial. He grew well during the first 6 months of therapy, but his growth rate attenuated after 7 months of therapy. At the same time, he had a skin reaction at the injection site together with a high titer of anti-hGH antibody and a high serum concentration of IgE. He grew again after switching from $\mathrm{m}-\mathrm{hGH}$ to $\mathrm{p}$-hGH treatment, but the invidual values for the titer and binding capacity are not given in the literature. Our patient is the third case who responded well initially, but did not later because of the appearance of anti-hGH antibody.

It is well known that anti-hGH antibody could be a cause of growth attenuation during hGH treatment. However, growth attenuation caused by anti-hGH antibody is not seen often. Kaplan et al. (1986) reported that 21 of 22 patients treated with an early preparation of $\mathrm{m}-\mathrm{hGH}$ (G-08 Genentech; ECP $220 \mathrm{ng} / \mathrm{vial}$ ), and 6 out of 14 patients treated with a highly purified preparation (G-015 Genentech; ECP $<30 \mathrm{ng}$ / vial) developed an anti-hGH antibody during treatment. However, in all patients except one, the binding capacity was below $4.1 \mathrm{mg} / \mathrm{L}$. Bierich et al. (1986) reported that 32 patients were treated with the first preparation of $\mathrm{m}-\mathrm{hGH}$ (Somatonorm I, ECP $\sim 610 \mathrm{ng} / \mathrm{vial}), 12$ patients with the second batch of m-hGH (Somatonorm II, ECP 125 $\mathrm{ng} /$ vial) and 11 patients with highly purified m-hGH (Somatonorm III, ECP $<8 \mathrm{ng} /$ vial). The mean maximum titer expressed by $\log$ 10 of anti-hGH antibody in these three groups of patients during treatment was 3.1, 2.4 and 0.5 , respectively, with a mean maximum binding capacity of $0.66 \mathrm{mg} / \mathrm{L}, 0.24$ $\mathrm{mg} / \mathrm{L}$ and $0.0 \mathrm{mg} / \mathrm{L}$, respectively. Though the binding capacity seemed not to be extremely high, one patient showed growth attenuation.

In a Japanese study (Takano et al., 1986),
anti-hGH antibody acquired during $\mathrm{m}-\mathrm{hGH}$ therapy was detected in all patients treated with the first preparation of $\mathrm{m}-\mathrm{hGH}$ (Somatonorm I, ECP $220 \mathrm{ng} / \mathrm{vial}, \quad \mathrm{N}=12,3$ months trial), in $86 \%$ of the patients treated with the second batch of m-hGH (Somatonorm II, ECP ; 30-7 ng, $\mathrm{N}=15,6$ months trial) and in $76.2 \%$ of the patients treated with the highly purified preparation (Somatonorm III, ECP 4-3 ng, $\mathrm{N}=37,12$ months trial) developed an antibody during treatment. The relationship between the titer and the binding capacity of hGH antibody is shown in Fig. 2. Our patient who showed growth attenuation had an antibody with a titer of $10^{6}$ and a binding capacity 2.0 $\mathrm{mg} / \mathrm{L}$ after 9 months of treatment. $\mathrm{He}$ is

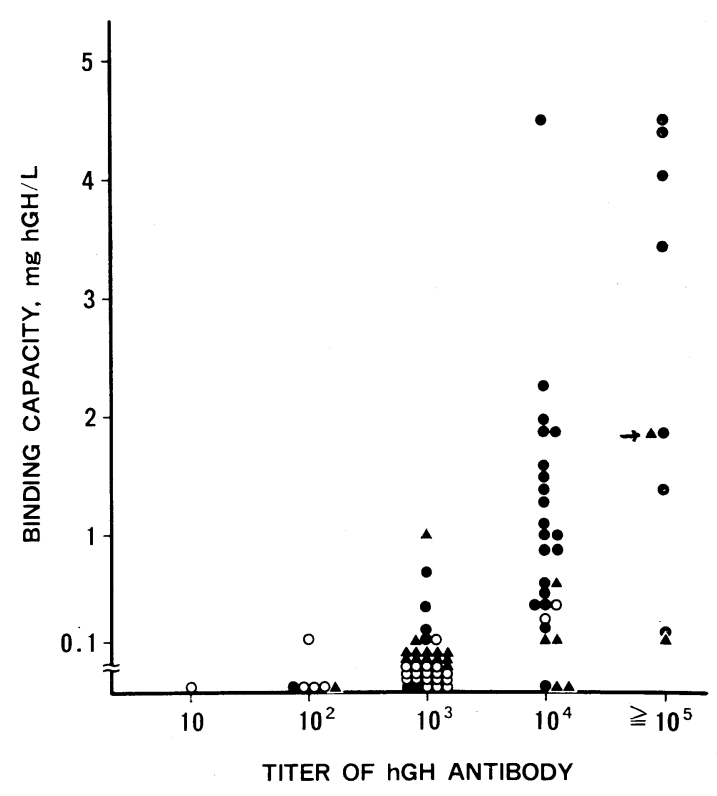

Fig. 2. Relationship between titer and binding capacity of hGH antibody, - patients treated with Somatonorm I, $\bigcirc$; patients treated with Somatonorm II, $\boldsymbol{\Delta}$; patients treated with Somatonorm III. The triangle mark with the arrow is the case presented in this report, and he is the only one who had a titer of hGH antibody of $10^{6}$. This Fig is the same as the one previously reported by Takano et al. (1986). 
the only patient who showed growth attenuation during Somatonorm III treatment. Other patients who had a high titer and binding capacity were treated with Somatonorm I for three months and switched to p-hGH after the cession of the clinical trial of Somatonorm I. In these patients, the effect of anti-hGH antibody on growth increase could not be evaluated because of the shortness of the period of treatment.

The causes of the antigenicity of $\mathrm{m}-\mathrm{hGH}$ were discussed previously (Takano et al., 1986). By the advantage of recombidant DNA technology, methionine-free hGH (r$\mathrm{hGH}$ ) is now available. We (Takano et al., 1987) reported the positive growth-stimulating effect and much lower antigenicity of r-hGH. Although the anti-hGH antibody produced by m-hGH treatment did not affect the height increase during one or two years of treatment, clinical experience with $\mathrm{m}-\mathrm{hGH}$ treatment is too limited to conclude that the immunocomplex of hGH antibody is safe. Therefore, the less antigenic preparation might be preferable for the long term treatment of $\mathrm{hGH}$ in the future.

\section{Acknowledgement}

The authors are very grateful to Sumitomo Pharmaceutical Co., Ltd. (Osaka, Japan) and KabiVitrum AB (Stockholm, Sweden) for supplying the methionyl hGH preparations used in this study. This report was supported by a research grant from the Foundation for Growth Science in Japan.

\section{References}

Bierich, J. R. (1986). Treatment of pituitary dwarfism with biosynthetic growth hormone. Acta Paediatr. Scand. (Suppl.) 325, 13-18.

Bierich, J. R., M. B. Ranke, P. Beyer, P. Bittner, H. Borkenstein, J. Brämswig, O. Butenandt, F. Kollmann, B. Stöver, H. U. Schweikere, K. D. Shönberg, U. Heinrich, W. Sippell, N. Stanke, H. Stolecke, P. Stubbe and
R. Ziegler, (1986). Therapie des hypophysären zwergwuchses mit rekombinantem menschlichem wachstumshormon. Deutche Med. Woch. 111, 483-489.

Girard, F. and M. Gourmelen (1986). Clinical experience with Somatonorm. Acta Paediatr. Scand. (Suppl.) 325. 29-32.

Greulich, W. W. and I. S. Pyle (1959). Radiographic Atlas of Skeletal Development of the Hand and Wrist, ed. 2. Stanford University Press, Stanford.

Kaplan, S. L., L. E. Underwood, G. P. August, J. J. Bell, S. L. Blethen, R. M. Blizzard, D. R. Brown, T. P. Foley, R. L. Hintz, N. J. Hopwood, A. Johnsen, R. T. Kirkland, L. P. Plotnick and R. G. Rosenfeld (1986). Clinical studies with recombinant-DNA-derived methionyl human growth hormone in growth hormone deficient children. The Lancet 1, 697700 .

Milner, R. D. G. (1986). Clinical experience of Somatrem: UK preliminary report. Acta Paediatr. Scand. (Suppl.) 325, 25-28.

Scatchard, G. (1949). The attractions of proteins for small molecules and ions. Ann. N.Y. Acad. Sci. 51, 660-672.

Takano, K. and K. Shizume (1986). Clinical Experience with Somatrem in Japan. Acta Paediatr. Scand. (Suppl.) 325, 19-24.

Takano, K., K. Shizume, N. Hizuka, A. Okuno, T. Umino, Y. Kobayashi, S. Kusano, H. Nakajima, M. Irie, I. Hibi, K. Kato, S. Suwa, T. Koshimizu, M. Ogawa, M. Sudo, H. Imura, Y. Okada, T. Kondo, K. Hashimoto, M. Miyao, H. Kohno, N. Iwatani and S. Ono (1986). Treatment of pituitary dwarfism with methionyl human growth hormone in Japan. Endocrinol. Japon. 33, 589-596.

Takano, K., K. Shizume, I. Hibi, A. Okuno, K. Hanyu, S. Suwa, H. Nakajima, T. Kondo, K. Kato, N. Iwatani, T. Momoi, K. Chihara, E. Shirakawa and H. Kondo (1987). Treatment of pituitary dwarfism with authentic recombinant human growth hormone (SM-9500). Endocrinol. Japon. 34, 291-297.

Vicens-Colvet, E., N. Potau, A. Carracosa, M. Albisu, M. Gusiñer, J. M. Cuatrecasas, B. Strindberg and H. Flodh (1986). Clinical experience with Somatrem in growth hormone deficiency. Acta Paediatr. Scand. (Suppl.) 325, 33-40.

Westphal, O. (1986). Experience with Somotonorm in Sweden. Acta Paediatr. Scand. (Suppl.) 325, 41-44. 